
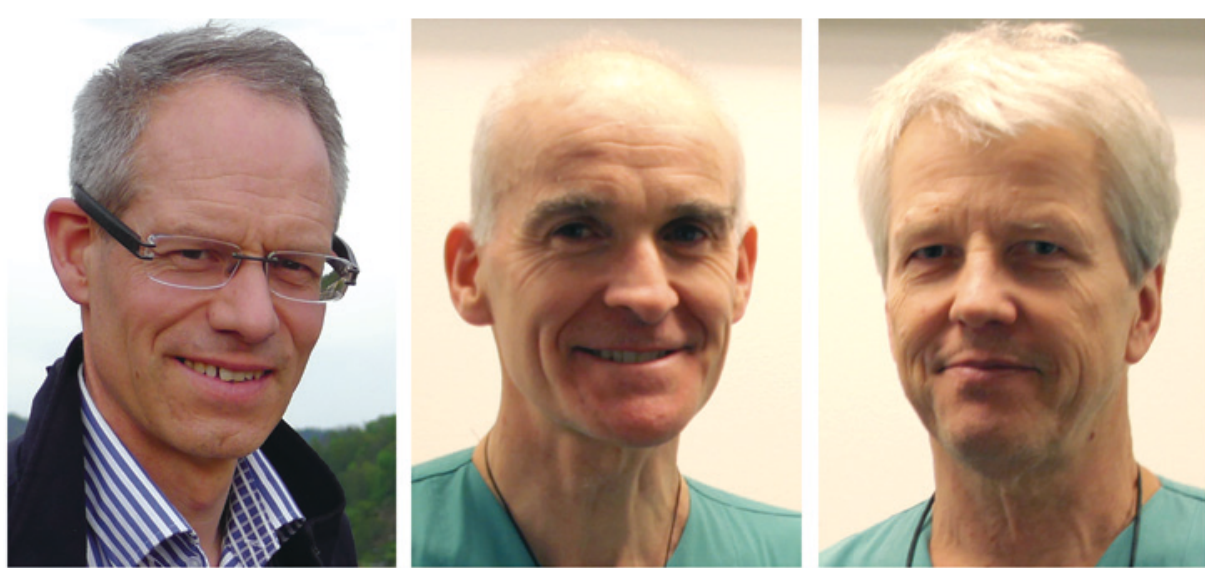

Fra venstre: Jørund Langørgen. Foto: Privat. Jan Hovdenes og Jan Frederik Bugge. Foto: Leif-Åge Øksenvåg, Thoraxkirurgisk avdeling, Oslo universitetssykehus

\title{
Terapeutisk hypotermi etter hjertestans?
}

Kontrollert temperatur på $36^{\circ} \mathrm{C}$ ga samme resultat som aktiv nedkjøling til $33^{\circ} \mathrm{C}$ etter hjertestans. Dette viser en fersk multisenterstudie med norsk deltakelse.

Hjertestans utenfor sykehus er forbundet med høy dødelighet og nedsatt nevrologisk funksjon hos dem som overlever. Terapeutisk hypotermi, dvs. nedkjøling til $32-34{ }^{\circ} \mathrm{C}$ i 12-24 timer, har vært anbefalt hos pasienter som ankommer bevisstløse til sykehus etter hjertestans, men dette er omdiskutert.

I en stor multisenterstudie ble pasienter etter hjertestans randomisert til å bli nedkjølt til enten $33{ }^{\circ} \mathrm{C}$ eller $36^{\circ} \mathrm{C}$ i 24 timer. Studien omfattet 950 pasienter fra 36 sentre i ti land, inkludert Oslo universitetssykehus, Rikshospitalet, og Haukeland universitetssykehus. Resultatene er nylig publisert i The New England Journal of Medicine (1). Andelen døde etter 180 dager var lik i begge grupper, hhv. $50 \%$ og $48 \%$. Det var heller ingen signifikante forskjeller i nevrologisk resultat, verken ved bruk av skåringssystemet Cerebral Performance Category (CPC) eller modifisert Rankinskala. Analysene ble justert for kjente prognostiske risikofaktorer, uten at det ble vist forskjeller mellom gruppene.

- Denne studien viser at nedkjøling til $33{ }^{\circ} \mathrm{C}$ ikke gir noen fordeler fremfor nedkjøling til $36^{\circ} \mathrm{C}$, sier Jan Hovdenes, overlege $\mathrm{i}$ anestesi ved Oslo universitetssykehus, Rikshospitalet, og medforfatter i studien. - Muligens skyldes den tidligere dokumenterte behandlingseffekten av nedkjøling fravær av feber, ikke en direkte positiv behandlingseffekt av hypotermi. Studien åpner for en gjennomgang av nåværende retningslinjer om nedkjøling til $32-34{ }^{\circ} \mathrm{C}$, med spørsmål om måltemperaturen skal endres til $36^{\circ} \mathrm{C}$, sier Hovdenes.

\section{Forskernettverk om hypotermi}

Studien ble initiert av personer innen Northern Hypothermia Network, som ble etablert for å gjøre registerstudier med hjertestanspasienter. Kontaktnettet er senere utvidet til å omfatte intensivleger i Australia og flere europeiske land. Overlegene Jan Hovdenes og Jan Frederik Bugge ved Avdeling for anestesiologi, Oslo universitetssykehus, og overlege Jørund Langørgen ved Avdeling for hjertesykdommer, Haukeland universitetssykehus, er norske medforfattere i studien. Den ble finansiert med svenske midler. Forskernettverket planlegger nå flere randomiserte studier med intensivpasienter innkommet etter hjertestans.

\section{Kari Tveito}

Tidsskriftet

\section{Litteratur}

1. Nielsen N, Wetterslev J, Cronberg T et al. Targeted temperature management at $33^{\circ} \mathrm{C}$ versus $36^{\circ} \mathrm{C}$ after cardiac arrest. N Engl J Med 2013; 369: 2197-206.
Ordforklaringer

Hypotermi: Definert som kroppstemperatur $<35^{\circ} \mathrm{C}$ og klassifiseres som mild $\left(35-33^{\circ} \mathrm{C}\right)$, moderat $\left(32-29^{\circ} \mathrm{C}\right)$ og alvorlig $\left(\leq 28^{\circ} \mathrm{C}\right)$.

Cerebral Performance Category (CPC): Et grovt skåringssystem på hjernefunksjon, hvor 1 er normal, 2 er lett nedsatt funksjon, 3 er alvorlig hjerneskade, 4 er koma og 5 er død.

Modifisert Rankin-skala: Et skåringssystem som har noen flere trinn og differensierer mer mellom grader av funksjonsnedsettelse enn CPC-skalaen. Den er primært laget for skåring av funksjonsnivået hos slagpasienter.

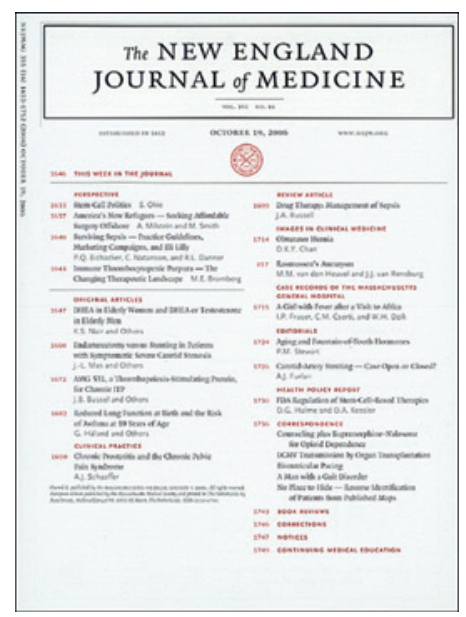

Artikkelen ble publisert i The New England Journal of Medicine, som er et av de mest prestisjetunge medisinske tidsskriftene, i desember 2013. 